\title{
O PONTO FORA DA CURVA DA RIBALTA EM A GLÓRIA E SEU CORTEJO DE HORRORES
}

\section{THE POINT OUTSIDE THE RIBALTA CURVE IN A GLÓRIA E SEU CORTEJO DE HORRORES}

\section{DOI 10.20873/uft2179-3948.2021v12n2p197-218}

\author{
Stephanie da Silva Borges ${ }^{1}$ \\ Esporas não possuo, para os flancos picar do meu \\ projeto, mas somente a empolada ambição que, \\ ultrapassando no salto a sela, vai cair sobre outrem. \\ Macbeth, ato I cena VII.
}

Resumo: Este trabalho procura examinar a maneira como o narrador-protagonista do romance A glória e seu cortejo de horrores, o ator Mário Cardoso, enquanto espelho da arte de seu tempo, não se posiciona de forma definitiva - como seria o esperado de um artista como ele e parece ficar na corda bamba entre a resistência e o conformismo diante da ditadura civilmilitar brasileira, muito em função de sua própria ambição.

Palavras-chave: ditadura civil-militar; ator; teatro político; televisão.

Abstract: This paper seeks to examine the way in which the protagonist-narrator of the novel A glória e seu cortejo de horrores, actor Mário Cardoso, as a mirror of the art of his time, does not take a definitive position - as would be expected from an artist like him - and seems to be on the edge between resistance and conformism in face of the Brazilian civil-military dictatorship, largely due to its own ambition.

Keywords: civil-military dictatorship; actor; political theater; television.

\section{Introdução}

A glória e seu cortejo de horrores é o segundo romance de Fernanda Torres, lançado em meados de 2017. O título é uma frase da mãe da autora, a atriz Fernanda Montenegro, a respeito da dificuldade enfrentada pelo ator em seu ofício, quando, depois da glória dos aplausos, este tem de esperar o horror de não repetir a boa atuação. Mestra na arte da tragicomédia, Torres propõe, neste livro, uma bem empreendida mescla de momentos tensos e de humor.

A narrativa, por sua vez, diferencia-se da de outros romances contemporâneos ligados

1 Doutoranda em Estudos de Literatura (UFRGS) e mestra em Literatura Brasileira (USP). E-mail: steh.borges@ hotmail.com ORCID: https://orcid.org/0000-0002-3764-9490 
(e até mais específicos) à ditadura civil-militar, pois não envolve algum trauma ligado à tortura ou ao exílio político, por exemplo. Todavia, a história do narrador-protagonista interessa não somente por abarcar o período mencionado, mas também, por propor uma nova forma de interesse pelos contornos do regime. Além disso, devido ao déficit de artigos sobre o livro estudado, a análise aqui ensaiada pretende ser um ponto de partida nesse sentido.

Falando de sua própria profissão, Torres apresenta ao leitor o ator Mário Cardoso, cuja vida acaba permeando a arte cênica no Brasil, dos anos 70 aos dias de hoje (o presente do livro parece se passar em 2017, ano de seu lançamento). Nesse tempo, a personagem - um artista genérico inspirado em muitos outros da vida real, como a própria autora frisa - tem por volta de 60 anos de idade e 40 anos de carreira, mas não aparenta ser tão idoso, visto que tem mãe viva. Fato é que, durante e depois do regime militar, a personagem não demonstra ter fortes ideologias, guiando-se apenas pelo cunho individual. Assim, Mário segue um caminho não óbvio para um artista que entra para as artes cênicas através do teatro político engajado, passa pelo desbunde hippie, pela dita contracultura, pelo Cinema-Novo, pelas grandes produções teatrais e entra para a maior emissora de televisão do país, sendo preso, já em declínio, não por sua atuação militante, mas por um homicídio que, acidentalmente, comete. No decorrer das páginas, contudo, vê-se que ele consegue angariar sucesso: da entrada meio incerta, chega à aclamação no teatro, faz novelas em uma importante emissora de televisão ${ }^{2}$ e, depois de experimentar de tudo um pouco e de pedir demissão, parte para um projeto pessoal de retomada da boa fase da carreira com a montagem de Rei Lear - este é o início da narrativa e quase o tempo presente. Ao contrário da expectativa, os finais de Mário e do livro põem-nos frente à decadência total, com a entrada do ator em um canal menor, seguida de sua prisão por assassinato.

Da glória aos horrores, altos e baixos da carreira, tudo é revisto pela memória do próprio Mário Cardoso, que sobrepõe lembranças marcantes da profissão, passando também por momentos familiares problemáticos: o Alzheimer e o suicídio da mãe, os contatos esporádicos com a família Tijucana "pobre", de quem sente pena, o casamento de quinze anos (e o fim deste) com a burguesa Marta, entre outros. Desse modo, ele vai construindo um mapa da cidade do Rio de Janeiro, cidade natal da autora, como pano de fundo, com várias indicações geográficas precisas. A narração em primeira pessoa dá lugar a um narrador em terceira pessoa nos dois últimos capítulos, os quais percorrem a trajetória do ator na prisão. No entanto, não há

\footnotetext{
${ }^{2}$ Subentende-se que a emissora seria a TV Globo, empresa que apoiou o golpe militar e que, até hoje, parece tentar se desvincular desse evento.
} 
juízo de valor por parte desse narrador, uma vez que apenas Mário julga a si mesmo: com riqueza de detalhes, ele traz discursos indiretos e faz uma autoanálise irônica, em geral, seguindo uma certa linearidade no que concerne à memória do passado mais antigo, intercalada com a de um passado recente.

Em certa medida, pode-se afirmar que o romance de Torres contraria a tese de Jaime Ginzburg (2012), pesquisador para quem a tradição da narrativa brasileira, conservadora e canônica - vale dizer, a qual sempre deu valor à cultura patriarcal, na voz de homens brancos não pobres, como é o caso de Mário Cardoso -, tem sido, desde os anos 60, desafiada por autores contemporâneos; estes, cientes da necessidade de se repensar a história diante das ruínas de catástrofes históricas (a violência ditatorial, por exemplo), priorizam elementos narrativos (temáticos e formais) diferentes dessa tradição, dando voz e relevo a figuras geralmente ignoradas ou silenciadas, pertencentes a grupos sociais historicamente reprimidos, excluídos ou tratados como minorias:

\begin{abstract}
A principal hipótese de reflexão consiste em que, na contemporaneidade, haveria uma presença recorrente de narradores descentrados. O centro, nesse caso, é entendido como um conjunto de campos dominantes na história social - a política conservadora, a cultura patriarcal, o autoritarismo de Estado, a repressão continuada, a defesa de ideologias voltadas para o machismo, o racismo, a pureza étnica, a heteronormatividade, a desigualdade econômica, entre outros. O descentramento seria compreendido como um conjunto de forças voltadas contra a exclusão social, política e econômica.

(...) Mesmo o conceito tradicional de representação, pautado pela mimese e associado à expectativa de uma homologia entre literatura e realidade, tem de ser reavaliado em tempos sombrios. Trata-se de falar, narrar, em condições que nunca foram possíveis, e interpretar o país a partir de horizontes historicamente condenados à mudez. Grupos sociais historicamente oprimidos elaboram, em novos autores, em narradores ficcionais, as condições para a presença dos excluídos. Escritores dispensados pelo cânone, grupos sociais reprimidos historicamente. (GINZBURG, 2012, p. 201-203)
\end{abstract}

Logo, as situações narrativas contemporâneas costumam expor pontos de vista considerados inferiores pela tradição, com interpretações históricas não hegemônicas, adotam uma perspectiva não mimética, visando ao debate, utilizam-se da fragmentação e abarcam o hibridismo de gêneros. Como se pode avaliar, isso não ocorre no romance estudado, no qual o narrador-protagonista espelha uma perspectiva mais tradicional, conforme a distinção proposta por Ginzburg (2012).

\title{
1 A trajetória de Mário Cardoso mapeia a arte no Brasil: o ator e o palco
}

\subsection{Rei Lear sem coroa}

O primeiro capítulo do romance, que gira em torno do fracasso da montagem de Rei Lear, de William Shakespeare, já nos apresenta a atual fase ruim de Mário Cardoso, tendo o 
estado das coisas na arte como eco. Subindo ao palco depois de o ator ter pedido demissão da grande empresa de TV, a peça é um projeto que se mostra faraônico com o tempo. Com ele, aparecem críticas ferrenhas e importantes ${ }^{3}$, desgostos com a equipe e sucessivos ataques de riso de Mário, que levam ao fim da temporada e a dívidas enormes. Além disso, durante as mesmas páginas, desponta a lei de incentivo através da qual a peça é viabilizada (uma espécie de analogia à Lei Rouanet, apesar de esta não ser mencionada no livro), regulamento que o contador e a produtora tentam erroneamente burlar para beneficiar o diretor de marketing da empreiteira, facilitador do projeto na empresa financiadora do espetáculo - vale destacar, tanto o leitor quanto o narrador-protagonista ficam sabendo apenas mais tarde que esse desvio foi o que gerou "o rombo" com o governo, anunciado no início da narrativa. Em suma, a primeira parte do livro, em que Mário vai de São Paulo ao Rio de Janeiro completamente inquieto, desnuda um artista brasileiro em busca de saídas para a situação da mãe doente (outro contratempo seu) e para uma situação financeira desesperadora.

\subsection{Teatro político engajado e copiado}

Em seguida, o capítulo dedicado ao teatro político merece destaque. Ainda jovem, entre as décadas de 1960 e 1970, Mário Cardoso entra para o teatro na faculdade de Arquitetura, influenciado por um professor de nome Campos. É notável que o interesse de tornar-se ator surge mais por vaidade de palco e prazer próprio - sede de nomeada ${ }^{4}$ - do que por qualquer outra ambição artística. Em vista disso, após algumas apresentações e salvas de palmas recebidas, ele vai para o Nordeste do país como membro de um grupo liderado por Campos. Durante suas férias escolares, eles pretendem conscientizar inúmeros trabalhadores de latifúndios por meio do teatro político engajado, então em voga, cujos expoentes eram o CPC (Centro Popular de Cultura) da UNE e o Teatro de Arena de São Paulo.

Recorrendo à ótica de Décio de Almeida Prado (2009) para nomear teatro político ${ }^{5}$ como tal, pode-se afirmar que, no Brasil, o teatro com este caráter irrompeu durante a década de 1950

\footnotetext{
${ }^{3}$ Uma das críticas nos leva a crer que seja uma referência à já falecida crítica teatral Bárbara Heliodora, grande conhecedora do repertório shakespeariano.

${ }^{4}$ Expressão cunhada por Machado de Assis para se referir ao desejo exagerado pela glória.

${ }^{5}$ Para um detalhamento em torno do assunto, sugere-se a leitura da dissertação $O$ teatro político brasileiro e as diferentes faces do seu engajamento, pesquisa na qual o teatro político feito no Brasil à época ditatorial foi estudado sob a ótica da existência, em nossa esquerda, de distintas formas de engajamento - conceito sintetizado, no trabalho mencionado, a partir de Sartre (2015) e Adorno (1973). Desse jeito, dentre os teatros que priorizavam o protesto contra o regime autoritário e começaram a tomar posição frente à perplexidade da cultura e da sociedade, havia, na segunda metade da década de 1960, a militância simpática com o público do Teatro de Arena, ao revisar a história nacional de forma mais didática (como em Arena Conta Zumbi), e a exposição brutal da desagregação burguesa do Teatro Oficina, radicalizando a realidade com violência estética (como o seu diretor realiza em Roda Viva). Portanto, para além das cisões na esquerda, pode-se crer em uma evolução da resistência teatral, dentro da qual oferecia-se novas maneiras de contestar o status quo: muitas vezes, os alvos eram os mesmos, como a
} 
e ganhou força na de 1960, sobretudo em São Paulo, quando a dramaturgia brasileira estava na ordem do dia com peças e autores nacionalistas e, mesmo, militantes, refletindo o engajamento da cultura do período como um todo. Como se sabe, após o golpe de 1964, apesar da presença da censura sobre a arte, muito se tematizou contra a ditadura, especialmente em cima dos palcos teatrais e musicais, alguns dos únicos lugares onde ainda era possível expressar opiniões e fazer resistência à repressão, evidentemente, com cautela e apoio do público. Desse modo, pode-se projetar que a nossa dramaturgia política se difundiu principalmente no período de dez anos nos quais se afirmou o paradoxo entre o autoritarismo político da direita e o questionado domínio cultural da esquerda, de Eles Não Usam Black-Tie, texto e espetáculo popular do Teatro de Arena, de 1958, até a montagem de Roda Viva, peça de Chico Buarque levada ao palco em 1968 por membros do Teatro Oficina.

É importante lembrar que as artes do espetáculo (teatro, cinema e música) estiveram à frente da vida cultural brasileira na época de "relativa hegemonia cultural da esquerda no país", enfatizada por Roberto Schwarz (1978, p. 62) em um importante ensaio, no qual ele afirma ter vindo do teatro de esquerda o primeiro grupo (Opinião) formado para protestar contra a ditadura, regime que pôs as liberdades em suspensão. Assim, liderados pela arte dramática, conforme Dias Gomes (1968), os movimentos artísticos passaram a incomodar quem detinha o poder.

Ainda na década de 1950, perante o predomínio do capitalismo, a tomada de consciência política do nosso subdesenvolvimento provocou o surgimento de inúmeros artistas de esquerda, ligados ou não ao Partido Comunista Brasileiro (PCB) e à militância, que já produziam obras socialmente preocupadas - essa consciência do subdesenvolvimento gerou uma literatura engajada. Como ratificação, Antonio Candido (1989) mostra a ideia da consciência política do escritor da época em relação a problemas que os indivíduos de esquerda queriam ver superados no Brasil. No teatro, a pluralidade de tendências cedeu à reflexão da temática social nacional; no entanto, a reação aos anos 40 não foi primeiramente ideológica, mas formal e experimental, através do nascimento do Teatro de Arena. Nele, o clima eufórico do desenvolvimento juscelinista e a ascensão de um pensamento de esquerda se fizeram sentir quando Augusto Boal retornou ao Brasil e se juntou ao grupo, recém fundido ao Teatro Paulista do Estudante (TPE, comprometido com ideias políticas de esquerda), e passou-se a discutir o teatro esteticista e

burguesia progressista (em torno do Partido Comunista), o governo militar e o capitalismo imperialista. Logo, procurando passar uma mensagem de viés político ao espectador, ambos os pontos de vista engajados demonstravam uma arte que toma partido, contestadora e engajada na sua realidade social, unicamente apresentando as problemáticas não do mesmo modo, com linguagens cênicas contrastantes e tornando rico o debate. 
burguês do Teatro Brasileiro de Comédia (TBC). Logo, a presença da realidade brasileira na produção do nosso drama do século XX, identificada e preocupada fundamentalmente com as parcelas mais baixas da população (representação de tipos e costumes populares), surge associada a um nacionalismo realista e crítico, o que leva o teatro à vontade de militar na luta pela solução do atraso do país, propiciando "um caráter político e programático" à arte, como dizem Diógenes André Vieira Maciel e Valéria Andrade (2005, p. 9). Assim, o debate entre conteúdo próprio e forma adequada vinha à pauta antes do advento do Arena.

Com Eles não usam black-tie, peça que inaugurou o ideário nacional-popular nos palcos brasileiros e o nosso teatro político enquanto sistema, finalmente se pôs em cena a vida difícil do operário brasileiro, pertencente a uma classe mais baixa. Dado o seu sucesso, o drama de Gianfrancesco Guarnieri, apesar de idealista, foi um estímulo para as melhores condições de produção e para o aumento da audiência, fomentando igualmente a afirmação de jovens dramaturgos, atores e diretores - ao redor do Arena, eles estavam empenhados na construção de uma necessária e consistente dramaturgia político-social, com linguagem e interpretação brasileiras -, o que coincidiu com a etapa do nacionalismo político. Dessa maneira, segundo Maciel e Andrade (2005), o teatro centralizado no povo ganhou espaço por meio de artistas inquietos com a situação e de obras que buscavam a perspectiva das camadas populares como ponto de vista e de partida para a criação cênica, tornando as bilheterias atrativas e organizando uma cultura nacional-popular em torno disso.

Conforme Marcos Napolitano (2001a, p. 104), estando em vigor uma cultura esquerdista e nacional-popular, de aliança entre povo e artista, houve "uma mudança estrutural na linguagem" artística dos espetáculos, transformação que contribuiu para uma renovação na estrutura da recepção, com um público "jovem, universitário, de esquerda”. Como enfatiza Gomes (1968), público este que veio a se tornar maioria em nossos teatros politizados, incentivando a criatividade e as experiências artísticas no terreno do engajamento, além de trazer benefícios econômicos:

Minha tese central é que o conceito de engajamento artístico de esquerda, a partir do final dos anos 50, deve ser pensado a partir dessas mudanças estruturais no campo artístico-cultural como um todo, processo que diluiu a "república das letras" em outras áreas artísticas, vocacionadas para o "efeito", para a performance, para o "lazer". Assim, o conceito de engajamento, tal como delimitado por Sartre - a atuação do intelectual através da palavra (articulada em prosa e ensaio), colocada a serviço das causas públicas e humanistas -, sofreu no Brasil (e em outros países, sobretudo da América Latina) uma releitura, com todos os problemas e virtudes daí decorrentes. Ao contrário do que defendia o filósofo francês, o espaço de atuação privilegiado do artista/intelectual de esquerda brasileiro não foi a prosa ou o ensaio, embora os anos 50 e 60 fossem pródigos também nesses gêneros, mas as artes que apelavam aos sentidos corpóreos, através de imagens, sons e ritmos. (NAPOLITANO, 2001a, p. 104) 
O dinamismo de públicos, formas e conteúdos revela que o teatro engajado dos anos 60 foi extremamente produtivo, atuando politicamente, apesar da censura marcante em pelo menos metade da década. Desse modo, com foco no lado social, a dramaturgia se agitou ao acompanhar o clima de radicalização política do país: o governo de João Goulart dava forças à esquerda, embora o PCB ainda estivesse posto na ilegalidade, enquanto o teatro se colocava a serviço direto da conscientização das faixas populares, por exemplo, através das experiências do CPC da UNE, criado no início da década, onde entravam o didatismo político e a revolução social, via resistência e panfleto. Após o golpe de 1964, com perseguições à esquerda e alguma censura, a arte cênica, identificada pela ditadura como simpática ao antigo regime, ficou sob ameaça, agindo dentro de uma pequena e controlável zona de liberdade: era-se complacente, porque o teatro agia sobre uma plateia reduzida e não imediatamente nas massas; entretanto, os sucessivos êxitos de público e a repercussão dos espetáculos advertiram as autoridades que limitavam a liberdade artística, o que culminou na primeira onda de repressão contra a arte da época (GOMES, 1968).

A propósito do romance, uma semelhança é digna de nota: assim como o Teatro de Arena realizara nos anos 60, pondo-se contra o latifúndio e a burguesia conformista (em parte, aliada ao PCB após o golpe dos militares) e tendo Augusto Boal (diretor e um dos expoentes do Teatro de Arena) como uma das referências, o grupo de Campos promove a referida viagem ao Nordeste. Na empreitada, eles chegam, até mesmo, a incorporar parte da comunidade camponesa em algumas de suas improvisações, mas, no geral, Campos mantém o patriarcalismo da militância "de cima para baixo" - tal característica é exatamente o que fizera Boal desistir da mesma forma de ativismo do professor.

Aliás, esse episódio é praticamente a cópia de um evento narrado na biografia de Boal, que igualmente se arrepende de ter ido tentar "ensinar" politicamente os lavradores no Nordeste. A desistência de Boal tem a ver com a negação do seu grupo de atores (e dele mesmo) na hora de pegar em armas e acompanhar os trabalhadores em seu levante contra os latifundiários. Por outro lado, o grupo de Campos acaba por fugir, indo de volta ao Rio de Janeiro, quando os trabalhadores os chamam para salvar a vida de um deles (mais inflamado com as ideias de revolução propagadas) das mãos do dono das terras. Vale dizer que Mário Cardoso achava a missão um "barco furado" (TORRES, 2017, p. 58), porque, para ele, os camponeses conheciam mais da vida do que o próprio professor. A respeito da semelhança, veja-se os trechos a seguir.

Primeiramente, Mário discorre sobre o fim do teatro político e engajado em sua vida, precedido pelo acontecimento relacionado aos camponeses: 
Ele está lá agora, disse o da Kombi, devem ter apertado e, a essa altura, já entregou o que sabe. Podem catar as armas, ordenou, a hora é essa.

[...] Nos viramos para o Campos incrédulos. Aquilo não estava incluído no estatuto da colônia de férias. Ele percebeu a contradição. Era um professor de teatro, sem talento para liderar uma ação suicida. E justo quando mais precisou, faltou-lhe a argumentação. Ficamos à espera de que o líder explicasse que éramos estudantes de arquitetura, artistas amadores, filhinhos de papai, inocentes virgens! Qualquer desculpa que o fizesse desistir da convocação. O tronco do ipê, aquele que nos dera boas-vindas no início, entendeu a demora e sacou o facão. Recuamos unidos e ele cuspiu no chão, para deixar clara a decepção. Vocês enchem a gente de ideia, disse ofendido, mas na hora da necessidade, não querem sujar as mãos finas. Se ninguém é homem aqui, eu sou, proclamou com o cenho fechado, e saiu porta a fora, seguido pelo Araújo e o resto. A escuridão deu cabo deles. O da Kombi ficou ainda um segundo, fuzilando o Campos com o olhar. Antes de seguir com a tropa, avisou que, quando voltasse, teria uma conversa séria com o grupo. [...] Fugimos a pé, sem arriscar palavra. Havíamos nos indisposto com o Cavalcanti e com os empregados dele, corríamos risco de cair numa emboscada, de acabar na cadeia, de ser torturados, mortos, vingados.

[...] Sepultei a luta armada, a militância, queimei as fotografias do Che, joguei fora o Marx, o Marcuse e o Brecht. A realidade é horrível, eu não queria mais saber dela. Covardia? Que fosse. (TORRES, 2017, p. 64-66)

Por sua vez, com o apoio do Movimento de Cultura Popular (MCP), o Teatro de Arena fez um intercurso no Nordeste (onde estaria o seu povo ideal, autêntico e desejado) no início dos anos 60; porém, Boal (2000) posteriormente critica o fato de, embora o povo participar do movimento, haver autoritarismo na relação entre artistas e plateias, isto é, a mensagem teatral vinha sempre acompanhada de uma simplificação exagerada da realidade social. $\mathrm{O}$ diretor nota isso ao mesmo tempo em que reprova as suas próprias intenções, ao reconhecer "a falsidade da forma mensageira de teatro político" (BOAL, 2000, p. 186), uma vez que não se deve incitar alguém a realizar ações que não se está preparado para realizar também, correndo os mesmos riscos:

Tínhamos feito um show, só para camponeses, que terminava com atores cantando frenéticas saudações revolucionárias, braço esquerdo levantado, punho cerrado: “A terra pertence a quem trabalha! Temos que dar nosso sangue para retomá-la dos latifundiários!" Coisas que todo mundo pensava e achávamos conveniente repetir. Arte da época.

Foi quando o camponês Virgílio, chorando entusiasmado com nossa mensagem, me pediu que, com o elenco e os fuzis, fôssemos com seus companheiros lutar contra os jagunços de um coronel, invasor de terras. Quando respondemos que os fuzis eram falsos, cenográficos, não davam tiros, e só nós, artistas, éramos verdadeiros, Virgílio não hesitou e disse que, se éramos de fato verdadeiros não nos preocupássemos: eles tinham fuzis para todos. Fôssemos apenas lutar ao seu lado. Quando lhe dissemos que éramos verdadeiros artistas e não verdadeiros camponeses, Virgílio ponderou que, quando nós, verdadeiros artistas, falávamos em dar nosso sangue, na verdade estávamos falando do sangue deles, camponeses, e não do nosso, artistas, já que voltaríamos confortáveis pras nossas casas. (BOAL, 2000, p. 186)

Mencionando a "síndrome Che", Boal (2000, p. 176-177) anteriormente já havia reconhecido o patriarcalismo na mensagem do Arena, com a intenção de "querer libertar escravos à força", como diz; desse modo, sabendo o que era certo, o teatro político mensageiro mostrava a vida dos pobres e oprimidos, abria seus olhos e os evangelizava - isso quando havia 
"povo" como público. Logo depois, revendo a pedagogia adotada, a companhia preferiu mudar de caminho, aumentando sua preocupação social e criticando os equívocos da aproximação autoritária com o povo.

No romance de Torres, diferentemente do esperado, Mário Cardoso vai, de certa maneira, contra Augusto Boal e a maioria dos membros do Teatro de Arena daquele momento, que continuam na militância. Assim, ele assume o teatro como seu métier, saindo da faculdade de arquitetura, mas abandona totalmente a arte didático-política e adentra, por acaso ou somente por curiosidade juvenil, o mundo do "desbunde" alternativo e da "hippongagem" carioca, tanto que entra no coro de Hair, musical em cartaz no Teatro Ipanema, ao qual assistira muitas vezes. Aqui, há outro elemento interessante de debate, pois, mesmo não abertamente, esse nicho da arte propunha um engajamento à revelia, ou seja, uma explosão estética contrária às práticas de Campos $^{6}$. O engraçado é que o ator fica tão à margem dos acontecimentos da ditadura que, entre praias antigas e drogas novas, a única referência à censura feita no capítulo é uma reclamação sobre a duração de apenas um minuto da nudez de Sônia Braga em Hair.

Nesse caminho, segundo indica Napolitano (2001a, p. 104-106), a presença de novos segmentos sociais na recepção e a urgência de se construir popularidade aos artistas de esquerda, instalada desde a passagem aos anos 60, ajudariam a realizar os objetivos políticos próprios ao engajamento por meio da consolidação de um grande público (imediato, frequente, fiel e ideologicamente próximo) e da ampliação de "circuitos de mercado", o qual desejava-se profissional e de massa, sem desaguar na indústria cultural, agindo sobre o meio estudantil e o popular - o mercado foi um dos caminhos à popularidade da arte engajada, que, depois da homogeneidade inicial, especificou sua audiência conforme cada ramo artístico. Igualmente, Napolitano (2001a, p. 109) ressalta que uma parte importante da nossa arte engajada buscou estrategicamente as massas; por outro lado, a conquista dos jovens e o limite das classes médias garantiam a identificação entre palco e plateia, sendo esta empática à cultura nacional-popular,

\footnotetext{
${ }^{6}$ Quanto ao engajamento ligado à literatura (ou ao teatro, neste caso), termo surgido junto à esquerda do século XX, em geral, diz respeito a uma criação ou prática diretamente entrelaçada com a política e, dentro disso, corresponde à manifestação de tomadas de posições, diálogos sociais e combates implicados nesse cenário. Logo, um autor engajado faria política na e através da sua arte, como defende o pesquisador Benoît Denis (2002). Assim, defendemos como engajada a arte largamente vinculada às preocupações político-sociais do período em que se dá - no Brasil, havia um teatro que agia em consonância com os propósitos da esquerda (a oposição) relativamente à ditadura civil-militar e ao imperialismo capitalista, reagindo contra o regime, desoprimindo a população, denunciando os abusos, entre outras coisas. Ainda, é interessante notar que, antes do golpe de 1964, o engajamento era claro nos espetáculos críticos ao mundo capitalista e pró revolução popular, mas, depois do estabelecimento do autoritarismo, o alvo passou a ser a ditadura como um todo. O engajamento, então, é o elemento demonstrativo de que o golpe civil-militar acirrou as contradições do capitalismo (concentração de renda, desigualdade social, entre demais fatores), não expressando somente uma contrariedade ao governo ditatorial como resultado. Adiante, o contexto mundial do final da década era de guerras e contrastes, como capitalismo versus comunismo, influenciando toda a arte de contestação que insurgia. (BORGES, 2019)
} 
que “implodiu” entre 1967 e 1968, como o próprio público:

Paradoxalmente, após 64, o teatro de esquerda, marcado por esse espírito cívico de protesto/resistência e pela busca de encenação do otimismo e da crítica da "cultura popular", ampliará seu público, sobretudo entre os mais jovens, potencializando um processo histórico já notável no final dos anos 50. [...] Mesmo enfatizando a "cultura popular" e criticando algumas ilusões políticas da aliança de classes defendida pelo PCB (como a crença na "burguesia progressista"), o teatro de esquerda pós-golpe (Arena e Opinião, sobretudo) ainda manteve a perspectiva básica da "frente" política derrotada em 1964. Até um certo momento, por volta de 1966/1967, seu público fiel parecia homologar essa opção. (NAPOLITANO, 2001a, p. 110)

Sobre a época, Napolitano (2001a) e Gomes (1968) asseguram que as principais pressões políticas e econômicas sobre o teatro vinham do controle exercido por um público pequeno-burguês, visto que a necessidade de agradá-lo era uma condição para a arte, mas da qual ela também podia se retirar por uma responsabilidade cultural e histórica; assim, uma nova reestruturação se deu na recepção após o nacional-popular, a partir de 1967, com o teatro indo contra a plateia da camada média, problematizando esse projeto de educação e assinalando a crise na assistência da arte engajada, ocorrida entre 1965 e 1968. Aliás, parte desse público "aprovou" o teatro de esquerda brasileiro de traços antiburgueses, inclusive aceitando ser agredido por ele - a radicalidade disso habita as peças "agressivas" de José Celso Martinez Corrêa, que, para alguns de seus críticos, provocaram mais incômodo do que consciência política ou a desejada tomada de atitude da plateia, mesmo tendo aberto novos rumos pelo rompimento violento de convenções proposto (GOMES, 1968). Dessa maneira, o teatro passava a se questionar:

Na medida em que a radicalização política tomava conta da vida nacional, o teatro
iniciava um debate que iria explodir no final da década de 60 , lastreado por novas
questões: para quem se deve encenar? Para o "povo" ou para a "pequena burguesia",
público tradicional dos teatros desde o final dos anos 40 ? Como devem ser trabalhados
os dilemas nacionais? Pela emoção, catarse e identificação entre público e palco? Ou
pela busca do distanciamento e do choque com a platéia? (NAPOLITANO, 2001a, p.
109)

De tal forma, "a nova radicalização política”, juntamente com uma cisão na intelectualidade esquerdista e uma mudança no meio estudantil - o teatro seria esmagado por essas transformações - finalizou a implosão relativa ao público em 1967, antes da promulgação do AI-5, não sendo este um processo consciente, mas concernente à "construção de uma sociabilidade de esquerda", segundo Napolitano (2001a, p. 110-111), que também aponta o fato de a esquerda "hegemonizada" (em torno do PCB) ter se fragmentado a partir disso e a juventude ter se dirigido para uma contracultura; nessa linha, dentre as duas propostas dramatúrgicas mais expressivas desse fim de década, teríamos o Oficina (sensivelmente crítico à política e à ideologia do partido) e o Teatro da Universidade de São Paulo, o TUSP (possuidor 
de uma dramaturgia de resistência e apologia à luta armada), os quais, no final dos anos 60, vieram a se articular contra a dramaturgia advogada pelo Partidão, ligada ao conceito de “nacional-popular". Como explica Napolitano (2001a), os impactos de 1968 desarticularam as certezas sociais e ideológicas de um público coeso e crescente, até mesmo afastando a burguesia dos espetáculos, uma vez que a ousadia da forma, importante para uma renovação teatral, forçava os limites de gosto e assimilação dessa plateia "média".

\subsection{Descobertas e perdas}

Outro capítulo marcante do romance é o que se refere à aclamada contracultura. Nele, Mário Cardoso conhece um diretor, Ernesto Guria, a quem admira, além do trabalho, pelo fato de este ter fugido da ditadura argentina. Com ele, o ator adota uma tendência mais vanguardista em seu ofício, embora o hermano ainda fizesse teatro burguês. Nessa parte, há referências ao Teatro Oficina, de Zé Celso, como sabemos, um teatro paulista símbolo da contracultura no final da década de 1960, o qual, segundo Mário, é uma falha sua não conhecer pessoalmente a experiência no Teatro Ipanema era o seu máximo contato com a revolução estética, até então. Nesse rumo, é montando Tchekov ao lado de Guria que o ator se torna um "sex symbol" da chamada contracultura, consegue fazer despertar o seu amor (tanto pelo teatro quanto por uma atriz, sua companheira de cena, Raquel) e marca definitivamente o fim da militância teatral com mais qualidade em sua atuação, como se uma coisa anulasse a outra. Das sensações boas da época em que "aprendeu a ser ator", ele se lembra do assédio e da consagração como Astrov, em Tio Vânia. Ao mencionar a transformação de seu métier a partir do encontro com Guria, Mário opõe-se ao teatro engajado do seu passado recente:

\footnotetext{
Guria pedia suavidade, algo que nunca me fora exigido. Vacilei. Havia cinco anos, me dedicava a praguejar contra a injustiça no mundo, cuspindo indignação, exibindo regozijo didático. Eu era um extra no Ipanema, jamais havia enfrentado um diretor de verdade e descobria, ali, no teste com o xamã dos pampas que ignorava de todo meu métier. ser escolhido por Guria representava uma oportunidade palpável de ser resgatado do coro de fiéis fanáticos, das hostes de revoltados, dos crentes libertos, da panfletagem folclórica. Medo, surpresa, alegria, ódio, nojo e tristeza, esse era o meu escopo de ator, as emoções básicas que qualquer criança é capaz de imitar; mas os infinitos sentimentos que existem entre elas, a partir delas, o ajuste fino da minha profissão, esse era um campo desconhecido para mim. (TORRES, 2017, p. 96-97)
}

$\mathrm{Na}$ sequência, o ator narra a realidade paralela que viveu com Raquel - seguida pela degradação da atriz - ao aceitar seu convite para fazer Navalha na Carne, peça que lhe rendeu ainda mais assédio. Depois, há a entrada em grandes produções (o chamado teatrão), a ida para a Europa dos grandes festivais, com uma versão para a tela de Grande Sertão: Veredas (filme de Cinema Novo), e, ainda, na volta da viagem, há o ingresso na Rede Globo - conforme dito anteriormente, a emissora não é mencionada - nos anos 70, período que Mário faz questão de 
explicar, tentando afastar de si a imagem de "artista vendido à TV".

A respeito de Raquel, apesar de a personagem não tecer muitas relações diretas com a ditadura, uma menção é digna de nota: Raquel definha a partir do processo de Navalha na Carne, enquanto Mário culpa-se pela decadência e pelo suicídio dela, tanto que chega a se afastar do teatro. Porém, quando a atriz, já em processo de decomposição, é lançada como "estrela da ala chique da indústria da pornochanchada" (TORRES, 2017, p. 114), ele assiste a um de seus filmes e parece flertar com a tortura do regime militar. Sobre a película, na qual Raquel, cooptada pela guerrilha, vai de grã-fina à amante de uma ativista do ABC, Mário diz, mais uma vez, alfinetando a esquerda:

Só não deixei a sala porque a sequência emendava com os meganhas do DOPS metralhando o aparelho da suposta célula comunista, crivando de balas a amante esquerdista. [...] Saí do cinema enojado, pensando na razão dela ter se submetido àquela vulgaridade travestida de resistência política. As atrizes se sujeitavam a todo tipo de exploração, convencidas de que tirar a roupa era um ato libertário. (TORRES, 2017, p. 115)

Nessa breve passagem, a atração do ator pela cena na qual assiste ao massacre da esquerdista deixa entrever não apenas o seu ciúme no tocante à Raquel, mas igualmente, um certo gozo decorrente da violência do período.

Mais tarde, após a ocorrência de papéis menores e, como consequência, o pedido de demissão da famosa empresa (para a qual não consegue retornar), sucedido pelo fracasso de Rei Lear, vemos Mário Cardoso já como um produto obsoleto. $\mathrm{O}$ ator está em decadência, mas possui um prestígio anterior que lhe proporciona ao menos a entrada em uma emissora concorrente, a de novelas bíblicas (referência à Record, embora a emissora também não seja nomeada), o que pode lhe dar certo retorno em dinheiro. Isso é possível graças à ajuda de Lineu (seu parceiro em Rei Lear) para que entre em Sodoma, uma das novelas religiosas e ruins do momento. Além disso, a fim de pagar a dívida que assume com o governo - pela interrupção da peça e pela descoberta das "notas frias" dadas por seu contador ao empresário -, o ator faz um comercial de papel higiênico (de nome "Nobre"), trabalho que acaba por enterrar sua brilhante carreira. Infeliz e sem a mãe para cuidar, pois, intercalado a tudo isso, ela suicida-se de vez, Mário começa a beber e tem a ideia de montar Macbeth, outra peça de Shakespeare. Com o objetivo em mente, em uma madrugada, ele procura o contador, Gomes, para mandar tudo "à merda" e pôr a ideia em prática; entretanto, eles brigam fisicamente e, empurrado, Gomes acaba caindo da janela do seu próprio apartamento. Como consequência desse "acidente", Mário é preso e condenado a uma pena de quinze anos.

\subsection{Macbeth detento}


Pode-se dizer que os capítulos finais da narrativa dão uma noção da possível viravolta de Mário Cardoso: antes, voltado apenas a si mesmo, agora, contribuindo para o desenvolvimento alheio - embora sempre querendo agradar a todos.

Desse modo, na cadeia, além de ser muito ajudado pela tia e pela prima, que o visitam com frequência, o ator é, de certo modo, cuidado pela travesti Greta; por outro lado, como sabe atuar, ele acaba ajudando um grupo, liderado por um pastor, que aplica os conhecidos golpes do telefone. Fora isso, ele escreve o seu Rei Lear - compreende-se que a peça é o próprio início do romance de Torres -, envia o manuscrito a Lineu e recebe Macbeth do amigo, a peça que deveriam ter feito ao invés de Rei Lear. Por fim, Mário ganha o direito de dar aulas de teatro na igreja da prisão e o faz com gosto. Com um "empurrãozinho" de uma comitiva de direitos humanos que visita o presídio, ele monta Macbeth com alguns detentos e reconhece, afinal, os princípios didáticos de Campos, o professor militante - o ator chega a confessar que começara tudo por ele mesmo, mas que depois continuara por Greta e pelo pastor, que, sendo bom em mandar, daria um ótimo Lear:

Refez o processo que o levara até Macbeth, foi um desvio, concluiu, um desvio chamado Lear. O teatro é uma profissão perigosa. Mário falou de sua experiência na zona da mata pernambucana e o quanto ela o havia ajudado com os detentos; lembrouse do professor, Campos, da sua crença ingênua de que faríamos daqui uma Cuba, e lamentou que ele não estivesse vivo para presenciar o trabalho. (TORRES, 2017, p. 211)

Na ocasião de falar em depoimento ao documentário que a dita comitiva exibiria na Organização das Nações Unidas (ONU), de acordo com o trecho acima, o protagonista se emociona, fato que demonstra a sua nova fase, um pouco mais humana.

\section{A narrativa mapeia a ditadura civil-militar: o ator e a tela}

Ecoando em toda a primeira metade da carreira de Mário Cardoso, a ditadura civilmilitar pode ser mapeada no romance de Torres através da vida artística do ator. Como primeiro exemplo, temos o próprio narrador-protagonista, que entra e sai da militância político-teatral sem razões fortes, desapegado de princípios que o guiavam anteriormente. Sendo assim, o garoto da Tijuca é finalmente convertido em homem da zona-sul carioca por meio da fama e do casamento com a respeitável Marta. Como Mário é voltado a si mesmo desde o princípio, ele só consegue fazer algo pelos outros - ainda que indiretamente - ao final da narrativa, já na prisão.

É importante frisar que a perspectiva do livro não é declaradamente o olhar dos vencedores da ditadura, aqueles que passaram ao largo dos acontecimentos políticos-sociais do período; todavia, A glória e seu cortejo de horrores deixa em aberto um caminho para 
questionarmos as relações da esquerda e da direita com a arte. Conforme hipótese de Daniel Araão Reis em referência a Fim (primeiro romance de Fernanda Torres), durante fala em um evento sobre os cinquenta anos do golpe, realizado na Universidade Federal do Rio Grande do Sul (UFRGS), em 2014, pode-se afirmar a ideia de que a autora aborda personagens que passaram incólumes pela ditadura civil-militar, sem entrar efetivamente para a resistência ao regime, mesmo que esse fosse o caminho mais óbvio para eles - o argumento pode ser estendido para o seu segundo romance no momento em que é possível enxergar a superficialidade do envolvimento de Mário com a oposição.

Outro tópico de observação do nosso narrador-protagonista são o povo e a mudança deste. Em resumo, Mário assume que o seu povo (então sintetizado pela parte da família que mora no bairro da Tijuca) é alienado pela cultura de massas e deveria ter sido estudado em seu laboratório para interpretar Lear. Contrário a isso, o povo ideal, sonhado pelo engajado professor Campos (e buscado por seu grupo no Nordeste brasileiro), não teria nada a ver com a família tijucana nem com o povo favelado, que o ator vê no tempo presente da narrativa, quando reflete sobre a desigualdade social - o povo atual vive entre morros e metralhadoras.

Fazendo parte do povo de Mário Cardoso, em grande maioria, o público, essa parcela tão dedicada aos ídolos, igualmente muda com o tempo. Nesse conjunto, a televisão é um elemento importante para que os atores "subam na vida", mas também, acaba se tornando item insubstituível no alcance do olhar do público, como a família tijucana, por exemplo, a qual acompanha "alguma coisa" de arte somente pela TV - há a prima viciada em assistir à programação e os parentes empolgados com partidas de futebol. Sobre o mesmo item, o ator ainda compara o seu público real (composto por taxistas, a babá com quem discute, os pivetes que fazem piada dele, a família da Tijuca, etc.), formado depois da entrada na promissora televisão e com o qual é soberbo, com o público de Rei Lear, quase inexistente, haja vista o tamanho da plateia teatral. Quando se dá conta da diferença, Mário se questiona se ainda haveria público de teatro no Brasil e para quem ele faria determinadas peças, concluindo, talvez ironicamente, que o público em potencial terminara migrando para a Internet, pois o "funk da metralhadora"7 seria uma manifestação artística bem maior do que Rei Lear, conforme o ator.

Apesar da observação sobre o público, o próprio Mário Cardoso muda - e talvez, essa seja a característica mais visível do narrador-protagonista. Algumas transformações são mais notáveis, como a primeira, ocorrida na ocasião em que ele conhece o diretor Ernesto Guria, descobre-se ator de verdade e ajusta a sua arte, a qual, segundo ele mesmo, é superior àquela

\footnotetext{
${ }^{7}$ Canção do gênero funk mencionada pelo narrador.
} 
do início da carreira (e sem luta política, necessariamente). Já na idade madura, o ator desenha um paralelo sobre os dois pesos e as duas medidas de militância e dinheiro:

Quando comecei no teatro, éramos todos de esquerda, adoradores de Brecht, Górki e Arrabal. Dinheiro era sinônimo de desvio de caráter. Mas o mundo mudou e meus amigos duros se transformaram em párias de trattoria, vestidos de bermuda e chinelo, sem plano de saúde, carro ou perspectivas futuras. Enfrentei a frieza deles, mas tive uma colheita farta. (TORRES, 2017, p. 50)

Mudança igualmente merecedora de destaque é a que o amor de Raquel provoca em Mário - quando ele é capaz de ver-se vulnerável. Ainda, há uma alteração ocorrida na ocasião em que o artista vai se aburguesando desde o casamento com Marta, mulher que conhece no tempo da concepção do filme de Grande Sertão: Veredas. O encontro se dá através de uma ricaça, patrocinadora de cinema, visto que a sétima arte possuía uma indústria ligada à elite. Nesse período, a ambição de Mário Cardoso, cada vez mais atraído por dinheiro e transformado em argentário, muda a partir do trabalho mencionado e do encontro com a esposa, como demonstram os trechos abaixo:

Foi ali, no salão da fazenda centenária de Vivi d'Aleçon, que optei pelo futuro que me
distanciaria dos comunas das trattorias, da loucura por uma atriz camicase, da sujeira
das salas de ensaio e da boemia do Fiorentina. Ali, eu começava a ser quem sou hoje,
um ator acomodado, mancomunado com vampiros do erário. Meu equívoco foi
investir no Burguês Ridículo, quando Marta cobiçava Riobaldo.
[...] Que saída existe para um artista, pensei, que não a imolação visceral? Outros
profissionais comem, bebem, trepam, se divertem e até sofrem sem padecer dessa
escravidão. Eu não aguentava mais tanto experimento, desejava um emprego que me
permitisse sobreviver, e só. Olhei para Marta, aquela mulher inteira, sentada na
poltrona ao meu lado. (TORRES, 2017, p. 140-147)

A propósito dessa união, Mário nunca amou Marta, apenas queria reviver, com ela, a Helena, personagem de Raquel na peça de Tchekov. Esse casamento é, afinal de contas, um capricho dele que dura quinze anos, até ela se cansar do desamor e trocá-lo por um exilado político. Ao mesmo tempo, é importante dar relevo aos traços externos do narradorprotagonista, que vão revelando a sua mudança também por fora. $\mathrm{O}$ ator indica que, além de mudar de carro e vestimentas, troca de companhias - tudo isso ocorre quando o país sentencia o fim da ditadura, e ele, o do engajamento: "Tornei-me íntimo da boemia fina, pintores, jornalistas, cineastas e toda a MPB. A anistia irrestrita sepultava de vez a ditadura militar e o engajamento político diminuía ao ritmo de um hedonismo lascivo, ébrio, estonteante" (TORRES, 2017, p. 163).

Outro trecho, mais diretamente relacionado ao regime militar, é o que apresenta o leitor ao pai de Mário Cardoso, o já falecido Jorge Cardoso. De acordo com as breves palavras do filho, o pai era um liberal democrata, portanto, como é esperado, mais inclinado à direita contra o comunismo, ele achava que os militares iriam livrar o Brasil de virar uma Cuba. Como 
se não bastasse, Jorge era completamente indiferente à tortura de presos políticos, progredira na vida com a engenharia e tinha mais medo de ter um filho hippie, perdido na libertinagem, do que na militância e na luta armada do teatro engajado (afinal, a revolução é, também, estética). Para ele, na sociedade em que almejava viver, não havia lugar para o teatro - mesmo assim, o pai assistira a tudo de Mário. Logo, o velho orgulhava-se de ver o filho vivendo com a burguesa Marta. Mário não explora muito a figura paterna em sua narrativa para além desse retrato com tons de fascismo, o que sugere uma certa vergonha com relação ao pai.

Adiante, uma última temática que salta aos olhos do leitor e que avultava nos tempos da ditadura é arte como mercadoria, grande questão de discussão entre os anos de 60 e 70: uma das primeiras pessoas a pôr isso em debate foi o compositor e escritor Chico Buarque, em sua peça Roda $V_{i v a}^{8}$, de 1967, montada pelo diretor do Teatro Oficina, Zé Celso - que acabara de explodir todas as estruturas estéticas com o seu Rei da Vela antropofágico. No romance, a temática habita a carreira do ator na televisão.

Por sua vez, a TV Globo expunha como ninguém a polêmica arte versus indústria, mas continuava sendo um sonho (sobretudo de estabilidade) para muitos artistas, mesmo que a entrada na emissora significasse estar trabalhando para o regime autoritário, porque, segundo Mário Cardoso, muitos perseguidos políticos tinham um porto-seguro na empresa e podiam, dentro dela, propor conteúdos “de qualidade". Aliás, foram estes que se interessaram pelo ator quando da sua contratação, conforme ele diz, egocêntrico, ao nuançar o apoio da empresa ao golpe e ao suavizar mais o fato através do destaque dado aos esquerdistas e à excelência dos trabalhos.

A respeito do crescimento da televisão e de suas relações escusas com a ditadura, Napolitano (2001b, p. 90) esclarece:

Os anos 70 podem ser considerados a "era de ouro" da televisão brasileira. Foi naquela década que a televisão, como sistema de comunicação, e algumas emissoras em particular (como a Rede Globo) construíram seu poderio e estabeleceram seu lugar definitivo na sociedade e na cultura brasileira. Obviamente, a televisão era considerada pelos setores mais intelectualizados e engajados um grande instrumento de manipulação da opinião pública e de alienação das massas trabalhadoras, que tomavam contato com um mundo artificial e glamuroso, ao qual não tinham acesso real. Enquanto isso, a realidade - política, social e econômica - era mascarada.

\footnotetext{
${ }^{8}$ Roda Viva expõe o interesse comercial da indústria da cultura através das rápidas ascensão e queda de um ídolo popular cooptado e criado pela televisão, ligada à massificação e ao imperialismo cultural dos anos 60. Na referida peça, escrita por Chico Buarque em 1967, a televisão é denunciada em sua "época de ouro" como sendo um agente controlador das massas, a quem os artistas deveriam obrigatoriamente e superficialmente agradar, através de suas imagens, para obter sucesso junto ao "grande público". É sabido que os militares dos tempos de repressão usavam os meios de comunicação de massa para convencer a população, sobretudo a mais alienada, da positividade do país sob o regime - canalizando revoltas em potencial para o lado do conformismo satisfatório - e da criminalidade de seus opositores. Ela seria "um ópio do povo", como retratou o diretor do espetáculo, Zé Celso (BORGES, 2019).
} 
A aliança econômica da Rede Globo com o grupo norte-americano Time Life e as relações políticas do seu dono, o famoso Roberto Marinho, com os políticos da ditadura só reforçavam ainda mais essa visão. O "padrão globo de qualidade", tão decantado pela própria emissora, era, para os críticos de esquerda, a antítese da realidade brasileira, miserável e subdesenvolvida, mascarando um mundo cheio de contradições ao criar um produto cultural belo e asséptico.

É claro que a visão dos críticos é generalizadora, de acordo com Napolitano (2001b), pois a prática era complicada: na década de 1970, a TV estava ao lado do poder institucional; no entanto, vários programas eram feitos por profissionais que, não comprometidos com o regime ditatorial em voga, visavam à criação de uma reflexão por parte dos telespectadores proposição que, obviamente, ficava à mercê de restrições impostas pela censura (do Estado e das emissoras) e pelas limitações do próprio meio de comunicação, mais atrelado ao lazer e à atenção superficial do que à dita reflexão ativa. Assim, junto ao telejornalismo, gênero considerado estratégico para a formação de "uma opinião pública conformista", como destaca Napolitano (2001b, p. 9), a teledramaturgia surgiu na referida década e foi um fenômeno de público - como mencionado no próprio romance, é curioso que muitos dramaturgos que participaram dessa revolução eram ligados ao PCB, sendo, após 1970, vários destes contratados pela Globo e nela desfrutando de considerável liberdade de criação, a fim de diversificar a teledramaturgia com vistas a tendências realistas e sociológicas. O Jornal Nacional, angariando status de voz oficial, foi lançado ao ar em 1969 e nunca expunha conflitos ou dissidências políticas; dessa forma, nos anos 70, a Globo basicamente apostava em novelas, telejornais e programas de humor, enquanto a Record e a Tupi enfrentavam a decadência - principalmente a segunda, talvez por abrir-se mais para a esquerda, com a participação de figuras da resistência política em sua grade -, e ainda, como opção à "televisão de entretenimento", havia emissoras públicas educativas, consolidadas nos anos 80 (NAPOLITANO, 2001b, p. 92-93).

O mesmo pesquisador sublinha a edificação da televisão enquanto um "grande fenômeno sociocultural no Brasil" na década de 1970, todavia, disseminado entre as classes mais populares - como a da família de Mário Cardoso - apenas na década seguinte; para Napolitano (2017, p. 312-313), nesse tempo, a televisão, encabeçada pela Globo, ainda fazia sucesso entre a classe média urbana e escolarizada (sobretudo em horário nobre), que valorizava a teledramaturgia e o jornalismo de debate, entrevista e opinião. Na mesma emissora, antes do final da década de 1970, "a teledramaturgia de formato novo" (as séries) já expunha o clima de abertura política ao telespectador, como foi dito anteriormente, visto que muitos dos autores desses programas eram advindos de ramos da esquerda política, alguns com passagem pelo PCB, como refere Napolitano (2017, p. 314-315):

A programação da televisão corporativa ou independente, a partir do final dos anos 
1970, nos leva a refletir sobre as relações entre a cultura de esquerda, tomada aqui em sua expressão genérica, e a indústria cultural. Se, na canção, essa relação já se apresentava como orgânica e constituinte da moderna indústria fonográfica brasileira, na TV a teledramaturgia de esquerda, desde o grande sucesso de $O$ bem-amado, de Dias Gomes, também seguia o mesmo caminho. O estrondoso sucesso de Roque Santeiro, a telenovela proibida de 1975, mas lançada ao ar em 1985, depois do fim do regime militar, era a consagração definitiva desse tipo de teledramaturgia, que mesclava realismo, nacional-popular e comédia social.

As experiências teledramatúrgicas da Rede Globo não podem sem supervalorizadas como sinônimo da grade geral da TV brasileira, embora tenham sido fundamentais para consolidar o grande produto televisual, as telenovelas. Mas foi, efetivamente, na "abertura" que a TV tentou atrair um público que, via de regra, a desprezava como sinônimo de alienação.

Tendo isso em vista, talvez Mário Cardoso não esteja "forçando a barra" quando tenta disfarçar a negatividade de sua entrada na televisão, apesar de sugerir uma ideia de oposição entre TV e cultura, ou, até mesmo, entre TV e sensatez política. Tal pensamento comum pode ser desmantelado pela própria historiografia teatral brasileira, na qual há inúmeros artistas de luta (antes, durante e depois do período ditatorial) que ingressaram na televisão, entretanto, em sua maioria, sem deixar de lado a atuação para além dela - diferentemente da personagem analisada aqui.

\section{Considerações finais}

O romance de Fernanda Torres não é simples, pois apresenta um narrador-protagonista complexo e sacana, que, do alto de sua corda bamba encantatória, lança tiradas críticas à esquerda (quando se refere a seus ex-companheiros, ao professor Campos e à militância de Ernesto Guria na Argentina), ao povo brasileiro (na figura de sua família tijucana) e, um tanto menos, aos militares. Assim sendo, pontuar a ditadura civil-militar em A glória e seu cortejo de horrores enfatizando a trajetória de Mário Cardoso, no limite, comprova que ele não possuía um respeito muito profundo pela arte na qual entrara através da resistência política - esta, inclusive, não servia de nada, além de alimento para o ego do jovem, que se inflava em cima do palco. Isso se confirma quando ele, já não empolgado com o métier, mas ainda na TV classe A, confunde profissão com emprego, em princípio, duas coisas bem distintas: logo, em sua decadência, sem o prestígio de antes (angariado pelo cargo na Globo), o ator produz sua arte com a montagem shakespeariana e não obtém o retorno aguardado; por isso, ele parece ser um artista que se molda segundo as exigências do momento e a sua ambição por grandeza, tal como Macbeth, personagem de sua peça final.

O ego implacável de Mário Cardoso progressivamente se torna um guia de sua personalidade: fora o desejado salário, a entrada na televisão satisfaz suas ambições ligadas à fama, que o cega e dá prazer; em seguida, ao emendar novelas, o ator fica cada vez mais louco 
por si mesmo; já na ocasião do velório do pai, algo que o atrapalha em uma temporada teatral, ele chega a gostar da presença de fotógrafos; ainda, Mário é tratado como artista consagrado tanto na empresa que não queria trabalhar quanto no comercial de papel higiênico, o que ameniza a inferioridade dos papéis - isso pode ser estendido até o seu intercurso junto ao público popular, como a família da Tijuca, em meio a qual ele ainda era "alguém". Aliás, é pensando em pagar dívidas que o ator segue sua jornada, mesmo com a carreira já desonrada, segundo acredita - nesse período, sem grandes ambições e amor recebido, ele pensa em morte. Ironicamente, é Mário quem acaba matando uma pessoa; contudo, segundo o próprio, seria bom morrer e matar somente em cena, recebendo elogios pela boa atuação.

As aproximações entre Mário Cardoso e "o outro lado" político não acontecem apenas quando ele entra para o elenco da famosa televisão apoiadora do golpe, deixando as prioridades de sua carreira anterior completamente para trás (após o estouro com o diretor da contracultura), mas também, no episódio da prisão, por ligar-se a uma ala considerada conservadora, a do pastor, cujos "seguidores" assistiam assiduamente à emissora bíblica - atenuando esse dado, ele desenvolve uma amizade espontânea com a travesti Greta, encantada por teatro. De mais a mais, não se deve esquecer que o ator fora criado entre uma mãe cuidadosa e um pai de pensamentos retrógrados.

A propósito, sua mãe, Maria Amélia, é uma figura emblemática. Logo nos primeiros capítulos, a viúva nos é apresentada já doente, em fase de perda de memória, embora o Alzheimer nunca seja mencionado. Para além da alegoria que a sua doença possa representar no romance, enquanto símbolo da urgência de se preservar uma memória que se esvai, ela, profunda na opinião do filho, termina por suicidar-se, enquanto ele, raso na essência e na profissão, escolhe cultivar a memória curta $^{9}$ com relação à sociedade em que vive, aproveitando-se de seu status de artista a vida inteira. Porém, o trecho abaixo aponta que o esquecimento de Mário pode ser sintomático de toda uma geração e não uma obra do destino:

No Brasil, não se cultiva a memória política porque a anistia significou amnésia, o país se recusa a enfrentar seu passado, a rever os crimes cometidos, a expor as verdades perpetradas por um regime de exceção. Enquanto houver esse "vácuo de justica", ou seja, enquanto vigorar essa lei iníqua que perdoou os torturadores e os assassinos, o Brasil não ousará olhar para seu passado, continuará sendo um país desmemoriado, ou, como diz B. Kucinski, um país que sofre de Alzheimer. (FIGUEIREDO, 2017, p. 26)

Nesse caminho, defendendo que a ignorância e a indiferença imperam sobre o passado

\footnotetext{
${ }^{9} \mathrm{O}$ único acontecimento que retorna à narrativa como uma espécie de memória é a falta de ar de Mário, a qual, volta e meia, aparece como a memória física de um trauma - não de tortura, importante lembrar - dado que ocorre na passagem do túnel Rebouças, quando da revelação da dívida com o governo por causa do "rombo" em Rei Lear, entre outros momentos.
} 
em nosso país, Gagnebin (2010) afirma que a anistia acarretou a imposição de um silêncio em torno da ditadura no Brasil que possui relações diretas com os silenciamentos quanto aos torturados de hoje em dia; como é de se esperar, tal obrigatoriedade de esquecimento da dor não funciona a longo prazo, como amnésia duradoura, visto que a anistia foi uma pretensão de manipulação da memória, permitindo apenas a sobrevivência imediata da nação através de condições artificiais e provisórias. Conforme é possível notar na narrativa, à exceção de suas falas sarcásticas, direcionadas a militares e militantes, o ator opta pelo silêncio, não se pronunciando abertamente sobre a ditadura, e tampouco toma posição diante da situação dos sofredores do seu presente (como os moradores de favelas ou o amigo Jackson, que encontra anos depois como vendedor ambulante), limitando-se ao breve sentimento de pena.

Portanto, o presente texto demonstra que, embora Mário Cardoso tenha tido a empolgação pueril como "carta de apresentação" ligada à militância teatral, a qual o seduzia, ele passa na superfície desta e, no limite, acaba se conformando com a ditadura, da qual sai praticamente ileso, apenas tentando manter o seu patamar de vida, apesar de viver circundado pelo regime. $\mathrm{O}$ ator narra episódios de violência ao longo de sua história, todavia, entre esses, o único momento em que Mário sente medo de sofrer violência física ocorre ao final do capítulo do teatro político engajado, quando o seu grupo é ameaçado por latifundiários, de um lado, e por trabalhadores, de outro, acabando por fugir do sertão nordestino - onde fora tentar incutir consciência política nos camponeses, como vimos. Por fim, frente a essa figura duvidosa, o ponto fora da curva da ribalta, pode-se questionar até que ponto a classe artística estava realmente envolvida nesse processo político, para além das aparências.

Não menos importante é o fato, ressaltado pela crítica do nosso tempo, de o livro de Fernanda Torres ter chegado até os leitores em um momento singular para a arte brasileira, o de iminente ataque à cultura, a qual, de certo modo, sempre foi vítima de inúmeras tentativas de marginalização em nosso país. O que impressiona é a proporção gigantesca da maré conservadora pela qual temos passado nos últimos anos, não por mero acaso.

\section{Referências}

ADORNO, Theodor Wiesengrund. Engagement. In: ADORNO, Theodor Wiesengrund. Notas de literatura. Trad. Celeste Aída Galeão e Idalina Azevedo da Silva. Rio de Janeiro: Tempo Brasileiro, 1973. p. 50-71.

BOAL, Augusto. Hamlet e o filho do padeiro. São Paulo: Cosac Naify, 2000.

BORGES, Stephanie da Silva. O teatro político brasileiro e as diferentes faces do seu engajamento. 2019. 172 f. Dissertação (Mestrado em Literatura Brasileira) - Faculdade de 
Filosofia, Letras e Ciências Humanas, Universidade de São Paulo, São Paulo, 2019. Disponível em: https://teses.usp.br/teses/disponiveis/8/8149/tde-18112019-165045/pt-br.php. Acesso em: 15 jun. 2021.

CANDIDO, Antonio. Literatura e Subdesenvolvimento. In: CANDIDO, Antonio. A educação pela noite \& outros ensaios. São Paulo: Ática, 1989. p. 140-162.

DENIS, Benoît. Literatura e engajamento: de Pascal a Sartre. Trad. Luiz Dagobert de Aguirra Roncari. Bauru, SP: EDUSC, 2002.

GOMES, Dias. O Engajamento é uma Prática de Liberdade. Civilização Brasileira, Rio de Janeiro, ano IV, n. 15, p. 7-17, jul. 1968.

FIGUEIREDO, Eurídice. A literatura como arquivo da ditadura brasileira. Rio de Janeiro, 7 Letras, 2017.

GAGNEBIN. O preço de uma reconciliação extorquida. In: TELES, Edson; SAFATLE, Vladimir (org.). O que resta da ditadura: a exceção brasileira. São Paulo: Boitempo, 2010. p. 177-186.

GINZBURG, Jaime. O narrador na literatura brasileira contemporânea. Quaderni di letterature iberiche e iberoamericane, Milão, $\mathrm{n}^{\circ}$ 2, p. 199-221, nov. 2012. Disponível em: https://doi.org/10.13130/2240-5437/2790. Acesso em 2 jul. 2021.

HOLLANDA, Chico Buarque de. Roda Viva. Rio de Janeiro: Editora Sabiá, 1968.

LITERATURA E DITADURA: os cinquenta anos do golpe civil-militar e suas implicações na Literatura. 2014. Evento.

MACIEL, Diógenes André Vieira; ANDRADE, Valéria. Da militância teatral num universo de letras. In: MACIEL, Diógenes André Vieira; ANDRADE, Valéria (org.). Por uma militância teatral: estudos de dramaturgia brasileira do séc. XX. Campina Grande: Bagagem / João Pessoa: Idéia, 2005. p. 7-15.

NAPOLITANO, Marcos. A arte engajada e seus públicos (1955/1968). Revista Estudos Históricos, Rio de Janeiro, v. 2, n. 28, p. 103-124, jul./dez. 2001a. Disponível em: http://bibliotecadigital.fgv.br/ojs/index.php/reh/article/view/2141/1280. Acesso em 22 jun. 2021.

NAPOLITANO, Marcos. Coração Civil: a vida cultural brasileira sob o regime militar (19641985) - ensaio histórico. São Paulo: Intermeios: USP - Programa de Pós-Graduação em História Social, 2017. (Coleção entre(H)istória)

NAPOLITANO, Marcos. Cultura brasileira: utopia e massificação (1950-1980). São Paulo: Contexto, 2001b. - (Repensando a História)

PRADO, Décio de Almeida. O Teatro Brasileiro Moderno. São Paulo: Perspectiva, 2009.

SARTRE, Jean-Paul. Que é literatura? Trad. Carlos Felipe Moisés. Petrópolis, RJ: Vozes, 2015. 
SHAKESPEARE

William.

Macbeth.

Disponível

em:

http://www.dominiopublico.gov.br/download/texto/cv000081.pdf. Acesso em: 19 jun. 2021.

SCHWARZ, Roberto. Cultura e Política: de 1964 a 1969 - Alguns esquemas. In: SCHWARZ, Roberto. O pai de família e outros estudos. Rio de Janeiro: Paz e Terra, 1978. p. 61-92.

TORRES, Fernanda. A glória e seu cortejo de horrores. São Paulo: Companhia das Letras, 2017.

Recebido em 16 de outubro de 2021 Aceito em 26 de outubro de 2021 